\title{
HARMONI BUDAYA \\ DALAM RITUAL METHIKAN \\ DI MASYARAKAT DESA PANGKAH TEGAL
}

\author{
Elya Munfarida *
}

\begin{abstract}
Methikan Ceremony, also called slametan gilingan, is one of the ceremonies held by the community of Pangkah and Sugar Factory of Pangkah as the organizer. The ceremony was held to mark the harvest and the beginning of milling sugar canes at the same time. The ceremony was preceded by harvesting (Java: methik) sugar canes on sugar plantations owned by farmers and factories to be treated as a pair of bride and bridegroom. The implementation of methikan ceremony was based on the religious system that can not be separated from the view of life (weltanchaung) and the Javanese world view on the achievement of certain spiritual values such as calmness, serenity and inner balance through the appreciation of society, nature and supematural as an inseparable unity that must be actualized in appropriate actions.
\end{abstract}

Keywords: acculturation, Methikan, Slametan.

\section{A. PENDAhUluan}

Jawa merupakan salah suku di Indonesia yang memiliki kekayaan khazanah budaya. Berbagai macam budaya dan tradisinya, masih melekat dan dianut oleh masyarakatnya, bahkan mempengaruhi berbagai aktivitas sosial, politik, ekonomi, kultural, bahkan religius dari masyarakatnya. Oleh karena secara kultural, menurut Koentjarajakti, kebudayaan memiliki dua komponen pokok, yaitu komponen isi dan komponen wujud. Komponen wujud dari kebudayaan terdiri atas nilai-nilai budaya berupa gagasan yang sangat berharga bagi proses kehidupan, sehingga nilai budaya dapat menentukan karakteristik suatu lingkungan kebudayaan di mana nilai tersebut dianut. Nilai budaya langsung

\footnotetext{
-) Penulis adalah dosen tetap Jurusan Komunikasi (Dakwah) STAIN Purwokerto.
} 
atau tidak langsung akan mewarnai tindakan-tindakan masyarakatnya serta produk kebudayaan yang bersifat materiil. ${ }^{1}$

Kekayaan budaya Jawa ini tercermin dengan banyaknya upacara-upacara tradisional yang masih dipertahankan hingga sekarang. Upacara tradisional itu meliputi keseluruhan siklus kehidupan manusia sejak dalam kandungan, kelahiran, masa kanak-kanak, remaja, dewasa, berumah tangga hingga meninggal dunia.

Lebih dari itu, masyarakat Jawa juga masih melanggengkan upacara adat dalam memperingati peristiwa-peristiwa penting dalam kehidupan mereka. Sebagian upacara adat itu berubah menjadi satu ritus keagamaan atau ritus religius masyarakat Jawa. Ritus religius terpenting adalah slametan yang terdiri dari keterkaitannya dengan daur hidup, pertanian, peringatan keagamaan, syukuran, dan bersih desa. ${ }^{2}$

Pada prinsipnya menurut alam pikiran orang Jawa, keseluruhan bentuk slametan itu diorientasikan pada tujuan memelihara keseimbangan tatanan kosmik dalam rangka pencapaian keslametan dan kesejahteraan hidup, karena kondisi kosmik yang transenden diyakini berhubungan erat dengan kondisi duniawi. $\mathrm{Hal}$ ini membawa konsekuensi bagi kehidupan individu dan masyarakat. Berbagai macam ritus keagamaan yang terdapat dalam masyarakat Jawa merupakan cerminan bahwa semua perencanaan, tindakan, dan perbuatan manusia telah diatur oleh tata nilai luhur. Tata nilai luhur itu diwariskan secara turun temurun dari generasi ke generasi berikutnya. ${ }^{3}$

Salah satu upacara slametan yang hingga kini masih eksis dalam kehidupan masyarakat Jawa adalah slametan yang berkaitan dengan pertanian, di antaranya adalah upacara Methikan. Upacara ini merupakan jenis slametan yang dilaksanakan sebelum panen dilakukan. Upacara ini dikenal oleh masyarakat Desa Pangkah Tegal, yang dilaksanakan hanya pada saat menjelang panen tebu. Sementara panen hasil-hasil pertanian lain, seperti padi, jagung, kedelai, dan sebagainya, tidak dilaksanakan upacara Methikan. 
Dalam pelaksanaannya, upacara Methikan diikuti oleh warga Desa Pangkah beserta dengan PG (Pabrik Gula) Pangkah yang dalam aktivitas panen bertindak sebagai pihak yang memanen tebu sekaligus sebagai pengolah hasil panen untuk diolah menjadi gula. Keterlibatan PG Pangkah dalam upacara ini memiliki makna khusus terkait dengan relasi antara petani tebu dengan pihak pabrik yang memanen sekaligus yang mengolah hasil pertaniannya.

Bagi masyarakat Pangkah, upacara Methikan merupakan tradisi budaya yang terkait dengan sistem keagamaan dan sistem sosial yang dianut di tengah pluralitas budaya masyarakatnya. Keberadaan ritus slametan sebagaimana direpresentasikan dalam upacara Methikan, oleh sebagian komunitas partisipannya dipandang telah memberi arti penting bagi tatanan kehidupan budaya masyarakat dalam kerangka kohesi sosial. Dan implikasinya melalui pelaksanaan ritus upacara itu, kehadiran simbolsimbol keislaman sebagai medium ritual turut pula memperkaya khazanah pengetahuan masyarakat dalam rangka intensifikasi keberagamaan mereka.

Antara tuntutan kohesi sosial dan tuntutan intensitas keberagamaan terjalin suatu tatanan nilai yang didambakan dan dicitacitakan bersama dan secara fungsional terangkai dalam suatu acuan perilaku yang menopang tindakan keagamaan masyarakat pada pelaksanaan upacara slametan Methikan. Hal inilah yang menarik minat untuk mengkaji lebih jauh tentang harmoni budaya antara budaya Jawa dengan agama masyarakat setempat (Islam) dalam upacara Methikan yang dilaksanakan oleh masyarakat Desa Pangkah Tegal. Oleh karena itu, berdasarkan penjelasan di atas, secara spesifik masalah pokok ini dirumuskan dalam berbagai pertanyaan: 1) Apa dan bagaimana gambaran konkret upacara Methikan yang diselenggarakan oleh masyarakat Desa Pangkah Tegal?; 2) Apa wujud nilai budaya yang terkandung dalam upacara Methikan itu sejalan dengan fungsi sosial yang dimiliki?; dan 3) Sehubungan dengan itu, bagaimana pandangan teologis tokoh masyarakat terhadap budaya upacara Methikan? 


\section{B. SEJARAH UPACARA METHIKAN}

Upacara atau ritual selametan banyak dilakukan oleh masyarakat Jawa dalam hampir semua aspek kehidupannya. Upacara slametan, dalam berbagai bentuknya, merupakan beberapa manifestasi tradisi masyarakat Jawa untuk mengusahakan keselamatan dalam setiap aspek kehidupannya. Salah satu bentuk upacara slametan yang penting bagi masyarakat Jawa adalah upacara selametan pada saat panen. Di beberapa daerah di Jawa, upacara ini dilakukan khusus untuk panen padi, seperti kasus di Mojokuto dan Sentolo. Sedangkan tanaman-tanaman palawija tidak diadakan slametan ketika akan dipanen. Sementara di beberapa daerah yang lain, upacara slametan ini justru dilakukan bukan pada tanaman padi, melainkan tanaman tebu, khususnya di Tegal, Pemalang, dan lain sebagainya.

Eksistensi upacara panen padi ini memiliki akar mistis dari cerita Tisnawati dan Jakasudana. Tisnawati, puteri Batara Guru, jatuh cinta kepada Jakasudana, seorang manusia biasa. Dalam kemarahannya, ayahnya Tisnawati mengutuknya menjadi butiran padi. Karena iba melihat suaminya duduk termangu melihat perubahan bentuk istrinya, maka Batara Guru mengubah Jakasudana menjadi butiran padi juga. Ritus panen mengesahkan kembali perkawinan mereka, dan sering disebut temanten pari atau perkawinan padi. ${ }^{4}$

Sementara tentang upacara panen tebu, peneliti tidak menemukan referensi yang secara spesifik berbicara tentang akar budayanya. Namun demikian, dengan melihat persamaan antara upacara panen padi dengan panen tebu, maka pada dasarnya ada beberapa praktik budaya yang sama, sehingga bisa jadi upacara panen tebu memiliki akar budaya yang sama dengan panen padi. Hanya saja beberapa perbedaan antara keduanya menampilkan pengembangan terhadap tradisi upacara panen yang disesuaikan dengan situasi dan kondisi yang ada.

Mengenai asal usul upacara Methikan, pada beberapa referensi tertulis, belum memberikan informasi yang memadai, sehingga peneliti menemui Bapak Sukoco (57 tahun), ${ }^{5}$ yang pernah bekerja di PG Pangkah sejak tahun 1975. Menurutnya, istilah methikan 
berasal dari bahasa Jawa "methik" yang berarti mengambil atau memanen. Methikan berarti memanen hasil pertanian dalam hal ini adalah tebu. Dalam tradisi masyarakat Desa Pangkah, istilah ini secara spesifik digunakan untuk menandai awal masa panen tebu, sekaligus awal masa giling tebu. Agar segala hal dalam proses penggilingan berjalan dengan lancar dan tidak mendapatkan gangguan dari kekuatan-kekuatan adikodrati yang negatif, maka diselenggarakan slametan gilingan.

Menurut Bapak Supeno dan Bapak Sukoco, ${ }^{6}$ upacara Methikan ini sudah ada sejak Pabrik Gula Pangkah ini berdiri. Hal ini berarti upacara ini sudah ada sejak abad ke $18 \mathrm{M}$, tepatnya tahun 1832 , ketika pabrik ini mulai đidirikan dan beroperasi. Dalam dokumen brosur Argo Wisata PG Pangkah, upacara ini sudah dilaksanakan sejak lama dan biasa diselenggarakan di lapangan Dwi Windu yang terletak di sebelah Rumah Besaran, yang dihuni oleh Tuan Besar (Administratur). Nama lapangan Dwi Windu ini berasal dari bahasa Sanksekerta yang artinya "16 tahun". Nama ini diberikan karena pada saat pemberian nama, lapangan itu sudah berusia 16 tahun. Menurut para sesepuh Desa Pangkah, nama tersebut diberikan masyarakat pada saat Indonesia memproklamasikan kemerdekaannya. ${ }^{7}$

Sementara itu, siapa yang berinisiatif untuk mengadakan upacara Methikan, juga tidak ada informasi yang jelas. Namun dari beberapa tuan besar (atau sekarang administratur) yang memimpin PG Pangkah, ada satu nama yang sangat populer di kalangan masyarakat Tegal khususnya di Desa Pangkah, yakni Tuan Halbosh yang merupakan tuan besar pertama PG Pangkah sekaligus yang mendirikannya. Menurut cerita para sesepuh yang tinggal di Desa Pangkah dan sempat mengalami zaman Tuan Halbosh, mengatakan bahwa meskipun namanya seperti orang Belanda tapi sebenarnya Tuan Halbosh bukan orang Belanda. Beliau dikatakan masih keturunan orang Jawa yakni Mbah Semedo, bahkan masih memiliki hubungan kerabat dengan Mbah Wungu. Keduanya adalah orang yang sangat berpengaruh di lingkungannya, bahkan hingga saat ini masih banyak orang termasuk para karyawan pabrik yang berziarah ke makamnya 
sebelum upacara Methikan dilakukan. Namun dalam versi lain, beberapa sesepuh Desa Pangkah mengisahkan bahwa Tuan Halbosh memang keturunan Belanda, namun ia ahli berbahasa Jawa, memperdalam ilmu Jawa (kejawen) serta memiliki daya supranatural (kesaktian). ${ }^{8}$

Berbagai cerita mistis melingkupi kehidupan Tuan Halbosh, seperti mampu mengubah daun menjadi uang, memiliki istri bangsa peri, misteri kematiannya, dan sebagainya. ${ }^{9} \mathrm{Hal}$ ini menunjukkan kentalnya budaya Jawa dalam kehidupannya, bahkan hingga saat ini masih banyak orang yang meyakini kebenaran cerita-cerita tersebut. Kalau pun seandainya Tuan Halbosh adalah keturunan Belanda, namun cerita-cerita mistis ini menunjukkan bahwa ia memiliki ketertarikan yang kuat terhadap budaya Jawa, yang memungkinkannya mengadopsi tradisi-tradisi Jawa, seperti upacara Methikan. Jika Tuan Halbosh masih memiliki hubungan kekerabatan dengan Mbah Semedo atau Mbah Wungu, maka kemungkinan besar ia mengakomodir tradisi-tradisi Jawa terutama tentang upacara panen, yang di daerah lain justru dikhususkan pada tanaman padi.

Pengadopsian budaya lokal (Jawa) dalam aktivitas-aktivitas pabrik yang dikelola Belanda memiliki pengaruh signifikan terhadap penerimaan masyarakat terhadap eksistensi PG. Pangkah yang saat itu dikelola oleh pemerintah kolonial. Dari aspek politik kolonialisme pengadopsian budaya Jawa akan berpengaruh terhadap loyalitas petani dan para karyawan pabrik terhadap kebijakan-kebijakan pengelola. Masyarakat Jawa yang terlibat dengan pabrik akan merasa memiliki pabrik tersebut dan berupaya untuk melakukan perannya masing-masing agar halhal yang terkait dengan poduksi gula dapat berjalan dengan lancar.

Di sisi lain, setiap masyarakat atau komunitas akan selalu berupaya untuk menjaga kontinuitas tradisinya dengan tetap memelihara keberlangsungan budaya yang dimilikinya. Begitupun masyarakat Jawa yang memiliki komitmen sangat kuat untuk menjaga tradisinya. Oleh karena dalam pandangan dunianya, alam, masyarakat, dan kekuatan-kekuatan Numinus memiliki 
peran penting dalam kehidupannya, sehingga keselamatan hidupnya sangat bergantung pada bagaimana ia mampu berinteraksi dengan baik pada ketiga elemen tersebut. Interaksi-interaksi tersebut diwujudkan dalam berbagai bentuk upacara atau ritual, yang pada intinya ingin mendapatkan keselamatan dalam setiap aspek kehidupannya. Hal ini yang mendorong masyarakat Jawa untuk terus menjaga tradisinya meskipun saat itu PG Pangkah dikelola oleh pihak asing, yang nota bene tidak memiliki pandangan dunia dan tradisi tersebut.

Pengabaian terhadap karakter masyarakat Jawa tersebut pada gilirannya akan berimplikasi negatif terhadap kinerja para petani dan masyarakat Jawa yang menjadi karyawan di pabrik tersebut. Hal ini seperti yang diungkapkan oleh bapak Supeno, ${ }^{10}$ bahwa hingga saat ini sebagian karyawan masih memiliki keyakinan kuat bahwa kalau slametan gilingan atau Methikan tidak dilaksanakan, mereka khawatir akan terjadi hal-hal yang tidak diinginkan. Kondisi ini tentu saja akan berdampak pada kerja para karyawan, sehingga tidak dapat bekerja secara maksimal.

Secara teoretis, upacara Methikan hampir sama dengan upacara panen yang dilakukan di tempat-tempat lain, khususnya tanaman padi. Artinya, upacara Methikan juga diselenggarakan untuk menghalangi kekuatan negatif yang akan berpengaruh terhadap kualitas dan kuantitas hasil panen. Selain itu, dalam upacara ini juga diadakan semacam pernikahan dari hasil panen baik berupa padi ataupun tebu yang dihias dan kemudian diiring untuk dinikahkan seperti layaknya penganten, sehingga pasangan tersebut disebut temanten pari untuk tanaman padi dan temanten tebu untuk tanaman tebu. Setelah itu pasangan penganten diinapkan di suatu tempat, seperti pengantin manusia agar hasil panen melimpah.

Namun berbeda dengan temanten pari yang calon pengantinnya diambil dari tempat yang sama dari petani penanamnya, dalam temanten tebu, tebu yang akan dijadikan temanten diambil dari dua lokasi yang berbeda. Kalau calon pengantin putranya diambil dari kebun petani atau tebu milik petani, maka calon pengantin puterinya diambil dari kebun pabrik atau tebu milik 
pabrik. Begitu juga sebaliknya, kalau calon pengantin puterinya diambil dari tebu milik pabrik, maka calon pengantin puteranya diambil dari tebu milik petani.

Selain itu, upacara Methikan ini memiliki tingkat kemeriahan yang lebih tinggi daripada upacara panen padi. Oleh karena sebelum upacara inti Methikan ini dilaksanakan, terlebih dahulu ada aktivitas-aktivitas hiburan yang diikuti oleh umum. Kalau pada zaman dahulu aktivitas hiburan berupa pagelaran wayang kulit, dugderan atau ronggeng, dan lain-lain, maka pada saat ini jenis hiburannya disesuaikan dengan kondisi dan tuntutan saat ini, seperti orkes dangdut, lomba MTQ (Musabagah Tilawatil Qur'an), lomba kasidah, lomba volley, sepakbola, bulu tangkis, dan lain-lain. Selain itu, para pedagang dengan aneka dagangannya, akan berdatangan dan semakin memeriahkan suasana. ${ }^{11}$ Karena adanya keterlibatan banyak pihak dan masyarakat umum, maka upacara Methikan diidentikkan sebagai pesta rakyat. ${ }^{12}$

\section{PRAKTIK UPACARA METHIKAN}

Dalam budaya masyarakat Tegal, khususnya Pangkah, upacara Methikan merupakan tradisi budaya yang terkait dengan sistem keagamaan dan sistem sosial. Keberadaan upacara ini sebagai manifesasi Slametan gilingan, oleh sebagian besar partisipannya dipandang memberi arti penting bagi tatanan kehidupan budaya dalam kerangka kohesi sosial. Implikasinya melalui pelaksanaan upacara tersebut, kehadiran simbol-simbol keislaman sebagai medium ritual turut memperkaya khazanah pengetahuan masyarakat dalam rangka intensifikasi keberagamaannya.

Upacara Methikan termasuk upacara besar dengan tingkat kemeriahan yang sangat tinggi, karena melibatkan semua elemen masyarakat. Baik dari kalangan masyarakat Desa Pangkah, elemen pejabat, ulama, para pedagang, seniman, dan lain-lain, semuanya turut serta berpartisipasi dalam upacara tersebut. Semua orang sangat menantikan pelaksanaan upacara tradisional ini, baik dari kalangan masyarakat di sekitar PG Pangkah, orangorang di luar kota bahkan turis mancanegara. Selain itu, PG Pangkah sebagai penyelenggara upacara ini, selalu membentuk 
panitia khusus yang bertanggung jawab mengatur jalannya upacara agar berjalan dengan lancar, dan dana yang dianggarkan juga cukup besar. Hal ini menandakan bahwa upacara Methikan adalah memang pesta rakyat.

Secara umum, pelaksanaan upacara Methikan dapat diklasifikasikan dalam dua tahapan, yakni pra acara dan acara inti. Sebelum upacara Methikan dilaksanakan, ada acara hiburan yang diadakan secara meriah. Berbagai kesenian rakyat ditampilkan untuk menyambut pesta rakyat ini. Kalau pada zaman dahulu, hiburan-hiburan rakyat itu berupa pagelaran wayang kulit, ronggeng, orkes, dan kesenian Jawa lainnya. Namun seiring dengan perubahan zaman, jenis hiburan yang ditampilkan juga ada yang berubah. Kini hiburan yang ditampilkan adalah jenis hiburan yang mengakomodir tradisi Islam, seperti lomba MTQ (Musabaqah Tilawatil Qur'an), lomba Kasidah. Selain itu beberapa jenis hiburan rakyat, seperti sirkus, juga ikut memeriahkan acara upacara Methikan. Berbagai lomba yang berhubungan dengan olahraga juga diadakan, seperti lomba sepak bola, lomba bulu tangkis, dan lomba bola voli. Di samping acara-acara di atas, para pedagang ikut berdatangan untuk memasarkan dagangannya, dengan harapan mendapatkan keuntungan dari banyaknya masyarakat yang menonton berbagai hiburan tersebut.

Berbagai pihak yang akan berperan serta meramaikan hiburan rakyat, seperti para pedagang atau yang menampilkan tontonan dari luar akan datang ke PG Pangkah dan meminta izin untuk ikut meramaikan pra acara upacara Methikan. Panitia akan memberikan izin dan mengatur penempatan masing-masing jenis tontonan rakyat tersebut di lokasi yang telah disediakan.

Selain acara hiburan rakyat, ada aktivitas yang harus dilaksanakan sebelum pesta giling atau upacara Methikan, yakni ziarah ke makam Mbah Semedo di gunung Semedo. Beliau dianggap sebagai sesepuh pangkah sekaligus sebagai kerabat Tuan Halbosh yang menjadi pendiri pertama PG Pangkah yang namanya masih menjadi ikon dan legenda PG Pangkah. Kegiatan ini diikuti oleh segenap pimpinan dan beberapa karyawan PG Pangkah sebelum pesta giling dilaksanakan. 
Sebelum upacara Methikan atau pesta giling dilaksanakan, dilakukan proses pemilihan tebu yang akan dijadikan temanten. Kriteria tebu yang akan dipetik adalah yang sudah masak optimal sudah sudah tua dan manis, serta rendeman (kadar gula) nya sudah maksimal. Calon temanten tebu yang dipilih berasal dari tebu milik PG Pangkah yang berjenis KM A dan tebu milik petani atau APTRI (Asosiasi Petani Tebu Rakyat Indonesia) yang berjenis KM B. Kalau penganten putranya berasal dari tebu milik pabrik, maka pengantin putrinya berasal dari tebu milik petani. Begitu juga sebaliknya, kalau pengantin putranya berasal dari tebu milik petani, maka pengantin putrinya berasal dari tebu milik pabrik. Pemilihan penganten tebu dengan menggabungkan dua pihak, yakni tebu milik PG Pangkah dan tebu milik petani menunjukkan kerja sama, kemitraan dan kesatuan antara kedua belah pihak. Hal ini mencerminkan bahwa kapan pun dan dimana pun, keduanya harus bersatu agar panen raya dapat sukses tiap tahunnya. Tanpa adanya kesatuan, yang terjadi hanyalah kemiskinan, kehancuran, dan keterbelakangan.

Setelah dilakukan pemilihan, tebu yang telah dipilih dihias dan kemudian masing-masing diberi nama yang baik, karena diharapkan dapat memberikan hasil yang baik. Misalnya penganten putra diberi nama Moch. Zaedun dengan harapan hasil panen bertambah sehingga hasil tebunya pun juga bertambah. Sementara pengantin putri diberi nama Siti Khasanah dengan harapan hasil panennya akan baik. ${ }^{13}$ Di tempat methikan (di ladang tebu) dilakukan acara ritual slametan dengan mengucapkan doa selamat agar segala proses upacara dapat berjalan lancar (selamet). Acara slametan ini disaksikan oleh beberapa pihak, yakni kepala bagian tanaman, seksi tebang dan angkut, APTRI, muspika bahkan kapolsek juga turut serta hadir dalam acara tersebut. Setelah acara slametan selesai, kedua temanten tebu diarak dari tempatnya masing-masing menuju PG pangkah dengan menggunakan mobil diiringi oleh para karyawan dan diiringi pula dengan keseniankesenian seperti terbangan dan kuntulan, layaknya mengarak pengantin manusia.

Setelah itu, dilaksanakan upacara pernikahan di antara kedua temanten tebu tersebut, dengan prosesi ijab qabul, doa dan wali- 
mahan. Setelah ijab qabul temanten tebu diinapkan di bagian tebang dan angkut. Pada sore harinya sekitar jam 4 prosesi walimahan dimulai, dengan membaca yasinan. Acara ini dihadiri oleh berbagai pihak termasuk para ulama dan santri pesantren terdekat. Pada saat walimahan, para ulama memimpin membaca manakiban dan tahlilan. Sementara di sisi lain, di tempat yang berbeda, masyarakat juga menikmati pagelaran wayang kulit, yang diperuntukkan untuk menghibur masyarakat yang hadir guna turut serta meramaikan acara tersebut.

Keesokan harinya, kedua temanten tebu serta dua boneka penganten diarak dari bagian tebang dan angkut ke stasiun gilingan dengan dihias, layaknya penganten. Tidak ketinggalan sajian tumpeng juga ikut serta di dalam arak-arakan tersebut. Sukses tidaknya gilingan tercermin dari sinar pancaran atau aura temanten. Sepasang temanten tebu inilah yang paling awal untuk masuk mesin gilingan kemudian disusul tebu-tebu yang lain sebagai pengiring.

Di samping itu, di masing-masing stasiun (gilingan, pemurnian, penguapan, serta kristalisasi, puteran dan penyelesaian) yang berperan dalam proses penggilingan dan produksi gula juga diadakan slametan. Di stasiun gilingan misalnya, disajikan sesajen lengkap tumpeng, kepala kerbau atau kepala kambing dan teh, kopi, air putih, degan dan jajanan pasar. Penggunaan kepala kerbau atau kepala kambing dimaknai secara simbolik bahwa nantinya mesin gilingan bisa bekerja secara maksimal atau "makan banyak tebu", seperti halnya kerbau atau kambing yang makannya banyak.

Tidak adanya sesajen yang komplit, misalnya tidak ada kepala kerbaunya diyakini oleh sebagian karyawan akan berpengaruh terhadap ketidakselamatan dalam kerja mereka. Meskipun bagi beberapa orang, hal itu hanya sebuah sugesti, karena secara nalar maksimal tidaknya penggilingan tidak tergantung pada hal-hal yang bersifat mistis. Namun entah kebetulan atau tidak, di beberapa lokasi pabrik gula seperti Jatibarang dan Sumberharjo, ketika dalam melaksanakan slametan tidak disajikan kepala kerbau, maka terjadi hal-hal mistis seperti paku di poros engkol gilingan yang 
sudah ditancapkan dan dicor, bisa terlepas sebanyak 4 kali. Sementara di Sumberharjo, banyak karyawannya yang mengalami kesurupan. ${ }^{14}$ Kejadian-kejadian yang tidak diinginkan inilah yang semakin meneguhkan keyakinan sebagian karyawan bahwa ada kekuatan-kekuatan gaib yang dapat memberikan dampak negatif terhadap proses penggilingan, sehingga untuk menghindarinya dilakukan ritual slametan. Ketika tidak diadakan slametan menjelang giling, mereka merasa khawatir dalam bekerja.

Setelah proses giling dimulai, dan menghasilkan gula, maka gula pertama yang keluar gilingan akan dikarung dan dibagikan kepada anak yatim. Jumlah gulanya berkisar 2 karung. Selain itu juga pabrik memberikan santunan kepada sekitar 150-an anak yatim setelah walimahan. Berbagai aktiviats sosial ini dilaksanakan sebagai wujud rasa syukur atas berhasilnya proses gilingan dan sekaligus berbagi rezeki (keuntungan) dengan rakyat.

\section{NILAI BUDAYA DALAM UPACARA METHIKAN}

Manusia, menurut Ernest Cassirer adalah animal symbolicum. Artinya setiap gerakan atau aktivitas yang dilakukannya merupakan simbol yang memiliki makna. Oleh karenanya, budaya sebagai produk aktivitas kemanusiaan merupakan kumpulan simbol-simbol yang menyimpan makna yang dalam bagi pelakunya. Dengan demikian, nilai atau makna dari sebuah budaya tidak dapat dilepaskan dari entitas-entitas kulturalnya. Dalam hal ini, entitas-entitas tersebut tidak hanya sekedar praktikpraktik budaya yang tidak bermakna, tapi merupakan simbolsimbol yang memiliki nilai atau makna yang penting bagi pelakunya. Dengan kerangka ini, maka upacara Methikan sebagai salah satu budaya masyarakat Pangkah Tegal sarat akan maknamakna yang dalam dan penting bagi para partisipannya khususnya dan masyarakat Tegal pada umumnya.

Upacara Methikan merupakan salah satu bentuk upacara slametan yang dilaksanakan masyarakat Jawa menjelang panen tebu. Eksistensi upacara ini sangat penting bagi mereka, karena mereka memiliki pandangan hidup bahwa semua entitas yang ada di dunia berupa alam dan masyarakat memiliki keterkaitan 
dengan alam numinus atau entitas yang bersifat transenden. Keterkaitan ini menjadikan setiap aktivitas kehidupan masyarakat Jawa selalu dilingkupi oleh kekuatan-kekuatan adi kodrati, yang memiliki pengaruh sangat signifikan dalam kehidupannya. Kekuatan-kekuatan tersebut bisa berdampak positif ataupun sebaliknya berdampak negatif. Untuk menghindari dampak negatifnya, masyarakat Jawa melakukan upacara atau ritual yang berfungsi untuk menolak kekuatan-kekuatan adikodrati yang akan memberikan kesengsaraan. Upacara-upacara tersebut diselenggarakan untuk mendapatkan keselamatan, baik untuk diri, keluarga dan masyarakat sekitarnya, sehingga upacara atau ritualnya biasa disebut slametan.

Dengan kerangka teoritis ini, maka upacara Methikan dilaksanakan agar proses panen dan penggilingan tebu dapat berjalan lancar tanpa adanya gangguan-gangguan dari kekuatan numinus yang dapat memberikan dampak negatif. Dalam hal ini, masyarakat Pangkah harus melakukan interaksi dengan alam gaib agar segala aktivitasnya di dunia terutama yang terkait dengan panen tebu, penggilingannya dan penyelesaian proses produksi gulanya, tidak mengalami kecelakaan atau tidak terjadi hal-hal yang tidak diinginkan. Hal ini secara eksplisit terlihat dengan dibacanya doadoa Islam yang intinya meminta keselamatan, baik ketika proses methikan, walimahan maupun ketika penempatan tumpeng di masing-masing stasiun.

Hal lain yang bersifat simbolik adalah adanya "dua temanten tebu", yang masing-masing temantennya diambil dari kebun yang berbeda, yakni dari tebu milik pabrik dan tebu milik petani. Hal ini berbeda dengan "temanten pari" yang calon pengantinnya diambil dari tempat yang sama dari petani penanamnya, yang secara simbolik dimaknai sebagai penyatuan kembali Jakasudana dan Dewi Sri yang dikutuk oleh Batara Guru menjadi padi. Sementara dalam temanten tebu, pengambilan calon temanten dari pihak pabrik dan pihak petani dimaknai sebagai wujud kemitraan dan kesatuan antara pihak pabrik dan petani dalam segala aktivitas yang terkait dengan penanaman, pemanenan, dan penggilingan tebu sehingga diharapkan akan mendapatkan hasil 
yang optimal. Hal ini sekaligus juga mencerminkan bahwa kapan pun dan di mana pun, keduanya harus bersatu agar panen raya dapat sukses tiap tahunnya. Tanpa adanya kesatuan, maka yang akan terjadi adalah kehancuran, kemiskinan, dan keterbelakangan.

Kedua temanten tebu juga diberi nama yang baik dengan harapan akan memberikan hasil yang baik pula dan akan menular ke tebu-tebu yang lain. Misalnya temanten putra diberi nama Moch Zaedun, dengan harapan hasilnya akan meningkat dan bertambah terus. Sementara temanten putri diberi nama Siti Khasanah, dengan harapan hasil panennya akan baik.

Dari kebun masing-masing, kedua temanten diarak ke pabrik dan dilangsungkan pernikahan di antara keduanya. Seperti layaknya pernikahan, ada prosesi ijab qobul, doa, dan walimahan. Adanya doa-doa, bacaan manakiban, dan tahlilan diharapkan segalanya akan berjalan dengan baik dan lancar tanpa adanya gangguan. Selain itu, cermin sukses tidaknya gilingan terpancar dari sinar pancaran atau aura kedua temanten itu. Penentuan hari pemethikan juga berdampak pada sukses tidaknya proses penggilingan.

Seperti halnya dalam upacara selametan, sesajen merupakan satu unsur penting yang harus ada. Salah satunya adalah kepala kerbau atau kambing. Penggunaan kepala kerbau atau kambing sebagai salah satu sesajen, menurut Bapak Supeno ${ }^{15}$ tidak dimaknai secara mistis bahwa kekuatan-kekuatan gaib memang menginginkan dan menyukai kepala kerbau tersebut, namun dimaknai secara simbolik bahwa nantinya mesin gilingan bisa bekerja secara maksimal atau "banyak makan tebu", seperti halnya kerbau atau kambing banyak makan rumput dan daun. Dengan bekerjanya mesin gilingan dan mesin-mesin yang lain, maka gula yang dihasilkannya pun akan melimpah dan berkualitas.

Selain simbol-simbol di atas, hal yang tidak kalah penting adalah banyaknya hiburan-hiburan rakyat yang ditampilkan dalam upacara Methikan. Upacara Methikan juga dikenal sebagai pesta giling. Artinya sebelum penggilingan diadakan semacam pesta rakyat dengan makna bahwa panen tebu dan penggilingan- 
nya itu ibarat panen uang yang selama ini ditanam. Keuntungan yang didapatkannya tidak hanya dinikmati sendiri tapi juga oleh orang lain atau rakyat. Oleh karenanya hiburan-hiburan itu memang diperuntukkan untuk menghibur rakyat, di samping juga memberikan manfaat ekonomis bagi para pedagang yang menjajakan dagangannya di sekitar tempat pelaksanaan upacara. Pesta rakyat ini juga sekaligus merefleksikan bersatunya pabrik dengan rakyat.

Di samping itu, ada tradisi untuk menyisihkan gula pertama yang keluar dari mesin giling. Gula tersebut kemudian dikarung dan tidak dijual, tapi diberikan kepada anak-anak yatim piatu. Hal ini juga menegaskan bahwa keuntungan tidak hanya dinikmati sendiri tapi juga berbagi dengan orang lain. Selain itu, tradisi ini juga merupakan wujud rasa syukur kapada Allah bahwa proses penggilingan dapat berjalan dengan lancar.

Dari berbagai makna atau nilai yang terkandung dalam upacara Methikan di atas, dapat dilihat bahwa masyarakat Desa Pangkah masih mempertahankan tradisi yang merupakan peninggalan nenek moyang orang Jawa yang sudah ada sejak zaman pra-Islam. Hal ini dapat dibuktikan dengan esensi dari slametan yang ada yaitu dalam rangka pemeliharaan keseimbangan tatanan kosmik untuk mencapai keslametan dan kesejahteraan hidup. Ada keterikatan antara manusia yang ada di dunia ini dengan alam Adi kodrati, sehingga dalam segala aktivitas yang berkaitan dengan daur hidup khususnya- sebelum dan sesudah melangkah harus diadakan slametan. Inilah yang disebut oleh Geertz dengan agama asli orang Jawa. Begitu juga kepercayaankepercayaan terhadap mahluk gaib seperti setan-setan dan rohroh leluhur yang dimungkinkan dapat mengganggu di satu sisi dan di sisi lain dapat membantu. Kepercayaan-kepercayaan tersebut pada akhirnya membentuk pandangan hidup orang Jawa di mana ia berada (javanesse world view).

Namun demikian, meskipun masyarakat Desa Pangkah masih mempertahankan ritus tersebut tetapi sudah banyak perubahan (sudah terjadi modifikasi) bentuk, isi, makna dan orientasi diadakannya ritus tersebut. Dari yang diorientasikan kepercayaan 
terhadap ruh nenek moyang, ruh-ruh halus dan dewa-dewa bergeser kepada Sang Khaliq, Allah SWT. Begitu juga dengan isinya yang mengalami perubahan, dengan dibacaknya doa-doa Islam dan manakiban (kalimat-kalimat thayibah dan shalawat atas Nabi SAW.), sehingga dapat dikatakan bahwa bentuk formalnya masih sama tetapi isi dan orientasi kegiatan tersebut sudah berubah. Inilah apa yang dikatakan dalam Antropologi Kultural dengan proses akulturasi dan adaptasi antara unsur-unsur budaya yang satu dengan yang lain sehingga muncullah harmoni budaya antara budaya Jawa dengan budaya Islam. Cara ini juga yang digunakan oleh para Walisongo dalam menyebarkan agama Islam di tanah Jawa agar tidak terjadi benturan yang tidak diharapkan. Begitu juga, agar Islam shalihun li kulli zaman wa makan maka dalam rangka Pribumisasi Islam -sebagaimana yang dikatakan Gus Durperlu mengakomodasi muatan-muatan lokal yang tidak bertentangan dengan ajaran agama Islam untuk tetap dipertahankan dan disyari'atkan. Inilah makna Islam yang universal, yang kosmopolit (rahmatan lil alamiin).

\section{E. FUNGSI UPACARA METHIKAN}

Pemahaman tentang upacara Methikan dalam keberagamaan masyarakat Pangkah, tidak terlepas dari konteks pandangan dunia (world view) orang Jawa. Menurut Magnis Suseno, ${ }^{16}$ tolok ukur arti world view bagi orang Jawa terletak pada nilai pragmatisnya untuk mencapai suatu keadaan psikis tertentu, yaitu ketenangan, ketenteraman dan keseimbangan batin. Oleh karena itu, keberadaan ritus slametan sebagaimana direpresentasikan dalam upacara Methikan, oleh sebagian komunitas partisipannya dipandang telah memberi arti penting bagi tatanan kehidupan budaya masyarakat dalam kerangka kohesi sosial. Dan implikasinya melalui pelaksanaan ritus upacara itu, kehadiran simbolsimbol keislaman sebagai medium ritual turut pula memperkaya khazanah pengetahuan masyarakat dalam rangka intensifikasi keberagamaan mereka.

Terkait dengan dasar pemahaman di atas, sejalan dengan kerangka konseptual penelitian ini yang berupaya menemukan 
fungsi upacara Methikan bagi masyarakat Pangkah, pada dasarnya dapat dijelaskan melalui kerangka pikir Merton, bahwa ritus mengandung dua fungsi utama yaitu fungsi manifes dan fungsi laten. Fungsionalisme sebagai perspektif teoretik dalam antropologi bertumpu pada pemikiran tentang sistem sosial budaya sebagai suatu macam organisme yang bagian-bagiannya tidak hanya saling berhubungan melainkan juga memberikan andil bagi pemeliharaan stabilitas dan kelestarian hidup organisasi itu. Dasar penjelasan fungsional adalah asumsi bahwa semua sistem budaya memiliki syarat--syarat fungsional tertentu untuk memungkinkan eksistensinya. Ataupun sistem budaya memiliki kebutuhan yang semuanya harus dipenuhi agar sistem itu dapat bertahan hidup. Jika kebutuhan sistem fungsional itu tidak dapat dipenuhi, maka sistem itu akan mengalami disintegrasi atau akan berubah menjadi sistem lain yang berbeda jenis. ${ }^{17}$ Dalam pengertian ini fungsionalisme merupakan asumsi bahwa setiap budaya adalah suatu konfigurasi unik tersendiri yang terbentuk dari bagian-bagian yang berinterelasi secara unik dan bagian-bagian tersebut harus dipahami hanya dalam kaitan dengan konteks konfigurasi yang luas itu.

Fungsi manifes merupakan konsekuensi atau fungsi yang disengaja dan disadari langsung oleh pelakunya. Dalam hal ini, upacara Methikan disadari secara langsung oleh pihak pabrik yang menyelenggarakan dan masyarakat secara keseluruhan sebagai partisipannya, sebagai upaya pemenuhan kebutuhan spiritual. Dengan keyakinan bahwa adanya kekuatan-kekuatan adikodrati yang dapat memberikan dampak negatif bagi kehidupan manusia, maka upacara Methikan atau slametan gilingan dengan segala prosesinya dilaksanakan untuk menghindarkan diri dari kekuatankekuatan jahat tersebut. Doa-doa yang dibaca adalah untuk memohon kepada Allah SWT agar diberikan keselamatan dan sekaligus dihindarkan dari marabahaya, sehingga proses pemanenan dan penggilingan dapat berjalan dengan baik. Adanya slametan ini, memberikan rasa kedamaian dan ketentraman bagi partisipannya, sehingga semua pihak dapat bekerja dengan maksimal. 
Mencermati motivasi keagamaan masyarakat Pangkah di atas, menunjukkan bahwa ritus Methikan dalam pandangan mereka telah berfungsi melayani kebutuhan mereka dalam mencari kebenaran untuk mengatasi dan menetralkan berbagai kemungkinan buruk dalam kehidupan. Hal ini didasari oleh alam pikiran mereka yang meyakini bahwa kehidupan di alam dunia ini senantiasa dihadapkan pada berbagai masalah kehidupan dunia yang merupakan bayang-bayang buruk. Oleh karena itu, solusinya diperlukan antisipasi penghadiran sikap hormat terhadap kekuatan gaib yang mengitari eksistensi kehidupan manusia. Pada akhirnya, budaya Methikan yang dahulunya adalah budaya murni Jawa, sekarang menjadi pandangan hidup orang Muslim Jawa.

Sedangkan konsekuensi atau fungsi yang tidak disengaja atau disadari langsung oleh warga partisipannya disebut sebagai fungsi laten. Fungsi laten dari upacara Methikan antara lain:

\section{a. Terpenuhinya kebutuhan integrasi sosial.}

Upacara Methikan yang disebut juga pesta giling, merupakan suatu sarana untuk menyatukan pihak pabrik dan pihak petani, sehingga upacara ini merefleksikan relasi kemitraan dan kerjasama di antara kedua belah pihak. Kesatuan antara keduanya secara harmonis akan berimplikasi terhadap kesuksesan panen raya tebu. Di sisi lain, upacara Methikan juga merupakan manifesasi bersatunya pihak pabrik sebagai salah satu elemen masyarakat Pangkah dengan rakyat di Pangkah pada khususnya dan Tegal pada umumnya.

\section{b. Terciptanya solidaritas sosial yang tinggi.}

Upacara Methikan dilaksanakan agar semua orang dapat menikmati keuntungan yang dihasilkan dari panen raya tebu. Artinya tidak hanya pihak pabrik saja yang mendapatkan keuntungan, tapi masyarakat juga dapat menikmatinya baik pihak petani, pedagang, dan masyarakat lain, yang merasa terhibur dengan adanya hiburan dan tontonan rakyat. Selain itu, tradisi memberikan gula yang pertama dihasilkan kepada anak-yatim piatu dan santunan-santunan lainnya menegaskan kuatnya fungsi solidaritas sosial di dalam upacara Methikan ini. 


\section{c. Meminimalisasi jurang perbedaan yang ada di masya- rakat}

Seperti sudah dijelaskan diatas, salah satu makna upacara Methikan adalah berbagi keuntungan dengan rakyat. Artinya kesejahteraan diupayakan dapat dinikmati oleh masyarakat yang lebih luas, tidak hanya pihak-pihak yang secara langsung terlibat dalam penanaman, pemanenan dan penggilingan tebu. Dengan adanya upacara Methikan, hampir semua elemen masyarakat bisa mendapatkan keuntungan baik yang bersifat material ekonomis dan immaterial. Selain itu, keterlibatan berbagai pihak dalam upacara ini, menunjukkan adnya relasi kesetaraan dan kemitraan di antara mereka, sehingga keberhasilan panen raya tidak hanya bergantung pada satu pihak tapi semua pihak ikut berkontribusi. Dengan demikian, secara sosial masing-masing secara fungsional memiliki peran-peran yang berbeda, yang dengan peran-peran tersebut masing-masing dapat memberikan kontribusi sehingga tercipta kondisi/tatanan yang equilibrium dan yang harmonis

\section{d. Penegasan dan penguatan kembali tatanan kultur masyarakat Jawa}

Masyarakat Pangkah menyadari bahwa pada hakikatnya upacara Methikan merupakan salah satu ritus keagamaan yang terdapat dalam masyarakat Jawa, yang merupakan cerminan bahwa semua perencanaan, tindakan dan perbuatan telah diatur oleh tata nilai luhur. Tata nilai luhur itu diwariskan secara turun temurun dari genarasi ke generasi berikut. ${ }^{18}$ Pelestarian upacara Methikan dan yang semacamnya merupakan upaya mencapai keselamatan dan kesejahteraan hidup. Hal ini disebabkan suatu kepercayaan bahwa manusia di dunia ini tidak dapat terlepas dari Yang Maha Kuasa. Oleh karena itu, segala aktivitasnya haruslah dipersiapkan sedemikian rupa agar terhindar dari segala hal yang tidak diinginkan. Persiapan dan antisipasi tersebut kemudian diwujudkan dalam bentuk slametan.

Atas dasar manfaat atau fungsi praktis sebuah upacara sebagai penentu pemenuhan kebutuhan spiritual untuk menemukan kejelasan terhadap fenomena alam, demikian pula pemenuhan 
kebutuhan sosial untuk mempertahankan solidaritas sosial dan pengendali moral masyarakat dengan mempertahankan tata nilai luhur yang ada, maka eksistensi upacara Methikan atau yang semacamnya, cenderung dilestarikan melalui sosialisasi dalam masyarakat dan diturunkan dari generasi ke generasi.

\section{F. PANDANGAN TEOLOGIS TOKOH MASYARAKAT TERHADAP PRAKTIK UPACARA METHIKAN}

Sebagaimana telah diketahui di atas, sejarah muncul dan berkembangnya agama Islam di Jawa tidak dapat dipisahkan dari akar budaya masyarakat Jawa. Islam datang dan berkembang dengan mengakomodir budaya lokal melalui akulturasi agama dengan budaya masyarakat setempat. Islam sangat menghargai adanya local wisdom (kearifan lokal), sehingga dalam perkembangannya tetap berusaha mempertahankan budaya-budaya lokal yang sesuai dengan ajaran agama kemudian diakomodir dan terjadi akulturasi budaya yang membuahkan budaya baru.

Demikian pula yang terjadi dengan budaya upacara Methikan. Budaya asli masyarakat Jawa khususnya Desa Pangkah Kabupaten Tegal dalam rangka slametan sebelum panen Tebu guna menjaga keharmonisan dengan alam Adi Kodrati. Dalam perjalanannya telah mengalami berbagai akulturasi dengan agama Islam sehingga praktik Upacara Methikan sudah banyak mengalami perubahan dari sebelumnya. Meskipun upacara sesajian (sesajen) dengan kepala kerbau, minuman, tumpeng dengan segala macamnya untuk roh-roh halus masih tetap ada namun upacara slametan Islami pun diadakan, yaitu dengan adanya pemberian nama Islami, upacara Siweran (dengan membaca shalawat), bacaan yasin dan tahlil serta manaqiban.

Adapun pandangan teologis dari para tokoh masyarakat terhadap praktik Upacara Methikan tersebut adalah;

a. Pandangan pengasuh Pondok Pesantren Kalikangkung Tegal. ${ }^{19}$ Ia mengatakan bahwa pada dasarnya dalam dakwah Islam itu yang ditekankan adalah dengan cara yang baik dan penuh hikmah. Sehingga dakwah Islam di tanah Jawa itu yang sesuai adalah apa yang pernah dilakukan oleh Wali Songo, yaitu 
dengan tetap mempertahankan budaya lokal tetapi pesan dan isinya diganti sesuai dengan ajaran Islam. Oleh karena itu, upacara Methikan adalah budaya masyarakat Pangkah dalam rangka sambut panen tebu, yang dahulu penuh dengan kemusyrikan sekarang diisi dengan nilai-nilai Islami.

b. Pandangan pengasuh Pondok Pesantren Darul Khair Babakan Lebaksiu Tegal. ${ }^{20}$ Islam mengenal adanya dua jenis makhluk, yaitu makhluk yang menempati alam materi dan makhluk yang menempati alam immateri. Makhluk yang menempati alam immateri (ghaib) ini adalah makhluk yang tidak dapat dilihat secara kasat mata oleh makhluk di alam materi termasuk manusia. Namun demikian keduanya harus menjaga keharmonisan dengan cara tidak saling mengganggu dunia mereka masing-masing. Oleh karena itu, dalam rangka menjaga keharmonisan tersebut, manusia dalam segala aktivitasnya perlu "minta ijin" kepada mereka "makhluk gaib" agar tidak mengganggunya. Salah satu bentuknya adalah dengan ritual/upacara Methikan yang merupakan budaya masyarakat Pangkah untuk meminta keslametan dan limpahan hasil panen yang maksimal dalam panen tebu. Namun demikian, permohonan keselamatan itu harus ditujukan kepada Allah SWT, bukan kepada yang lainNya, meskipun dengan beranekaragam ritual yang dilakukan.

Dari kedua pandangan teologis tersebut dapat disimpulkan bahwa, tokoh masyarakat menganggap praktik upacara Methikan sebagai bentuk permohonan keslametan dalam masa panen Tebu yang akan berlangsung adalah suatu wujud budaya yang masih harus dipertahankan dengan berbagai akulturasi budaya yang terjadi. Itu merupakan bentuk dari adanya kearifan lokal (local wisdom).

\section{G. KESIMPULAN}

Upacara Methikan atau disebut juga Slametan gilingan, merupakan salah satu upacara yang dilaksanakan masyarakat Pangkah dengan PG (Pabrik Gula) Pangkah sebagai penyelenggaranya. Upacara ini dilaksanakan untuk menandai masa panen dan sekaligus masa giling tebu. Pelaksanaan upacara ini melibat- 
kan seluruh elemen masyarakat Pangkah khususnya dan masyarakat Tegal pada umumnya.

Upacara Methikan ini diawali dengan memetik atau memanen tebu di kebun tebu milik petani dan milik pabrik untuk dijadikan sepasang temanten. Temanten tebu ini pun diberi nama yang baik dengan harapan mendapatkan hasil yang baik. Setelah diadakan slametan di kebun dengan bacaan-bacaan doa selamat, kedua temanten diarak ke pabrik dari tempatnya masing-masing dengan diiringi beberapa kesenian tradisional. Setelah sampai di pabrik kedua temanten tebu dinikahkan dengan melalui prosesi pernikahan layaknya pernikahan manusia. Setelah itu diinapkan di bagian tebang dan angkut.

Pada sore harinya dimulai acara walimahan, dengan diawali membaca yasinan, membaca manakiban dan tahlilan. Semua elemen masyarakat diundang, baik kalangan ulama, para pejabat eksekutif, kepolisian, dan masyarakat umum. Keesokan harinya kedua temanten ini diarak menuju stasiun giling untuk digiling pada kesempatan pertama, disusul kemudian tebu-tebu lain yang menjadi pengiringnya. Sukses tidaknya gilingan terpancar dari sinar pancaran atau aura kedua temanten tersebut.

Pelaksanaan upacara Methikan itu di dasarkan pada sistem keagamaan yang tidak terlepas dari pandangan hidup dan pandangan dunia orang Jawa tentang pencapaian suatu nilai psikis tertentu berupa ketenangan, ketenteraman dan keseimbangan bathin melalui penghayatan terhadap masyarakat, alam dan alam Adikodrati sebagai suatu kesatuan tak terpisahkan yang harus disikapi dengan tindakan tepat.

Berdasarkan informasi yang dihimpun melalui wawancara mendalam dan observasi, diperoleh gambaran adanya beberapa fungsi yang terkandung dalam pelaksanaan upacara Methikan bagi keberagamaan masyarakat Desa Pangkah Tegal, baik yang bersifat manifes maupun yang bersifat laten. Fungsi manifes tampak pada maksud pelaksanaan upacara Methikan itu sendiri sebagai upaya pemenuhan kebutuhan spiritual dalam rangka memohon kepada Allah SWT agar dihindarkan dari marabahaya dalam melaksanakan proses panen dan giling tebu. Upacara Methikan juga meru- 
pakan sarana mendekatkan diri kepada Allah, yang diyakini memiliki kekuatan dan kekuasaan untuk dapat memberikan kebaikan dan keslametan bagi manusia. Pemenuhan kebutuhan spiritual tersebut untuk menemukan kejelasan mengenai berbagai hal dari fenomena kehidupan di dunia dan hubungannya dengan alam Adikodrati. Adapun fungsi laten yang berupa pemenuhan kebutuhan sosial mencakup terpenuhinya kebutuhan integrasi sosial dan terciptanya solidaritas sosial yang tinggi, meminimalisasi jurang perbedaan yang ada di masyarakat serta penegasan dan penguatan kembali tatanan kultur masyarakat Jawa.

Sejalan dengan fungsi yang terkandung dalam pelaksanaan upacara Methikan di atas, pada dasarnya menyiratkan dua kawasan nilai yang ingin diraih, yaitu nilai spiritual dan nilai sosial. Kedua kawasan nilai-nilai ini, sehubungan dengan sistem keyakinan orang Jawa khususnya masyarakat Pangkah, merupakan dua entitas yang tidak terpisahkan sebagai gambaran pada hubungan alam kodrati dan alam Adikodrati dalam suatu keteraturan. Dalam perkembangannya Javanese world view yang ada dalam budaya Methikan setelah mengalami proses akulturasi budaya berubah menjadi pandangan hidup Muslim Jawa (Javanese Muslim's world view).

\section{ENDNOTES}

${ }^{1}$ Simuh, Sufisme Jawa, Transformasi Tasawuf ke Mistik Jawa (Yogyakarta: Bentang Budaya, 1995), hal. 110.

${ }^{2}$ Koentjaraningrat, Manusia dan Kebudayaan di Indonesia (Jakarta: Jambatan, 1975).

${ }^{3}$ Retno Sayekti, Upacara Tradisional Kelahiran Bayi Pada Masyarakat Jawa di Desa Tanjung Sari Kecamatan Batangkuis, http:www.litagama.org/jurnal/ edisi2/upacara.htm.

${ }^{4}$ Clifford Geertz, Abangan, Santri, Priyayi dalam Masyarakat Jawa (Jakarta: Pustaka Jaya, 1989), hal. 109.

${ }^{5}$ Wawancara dengan Bapak Sukoco pada tanggal 2 Oktober 2009.

${ }^{6}$ Bapak Supeno adalah orang yang saat ini menjabat koordinator operasional bagian tanaman di PG Pangka, Wawancara pada tanggal 14 Oktober 2009.

${ }^{7}$ PG Pangkah, Welcome to Argo Tour PG Pangkah Central Java, Dokumen brosur, hal. 26-27.

${ }^{8}$ Ibid. 
${ }^{9}$ Ibid., hal. 24-30.

${ }^{10}$ Wawancara tanggal 14 Oktober 2009.

${ }^{11}$ Wawancara dengan Bapak H. Syafi'i (68th) dan observasi tanggal 16 September 2009.

${ }^{12}$ Sumber dari Brosur AGROWISATA "LOCO-ANTIK" PG PANGKAH dan dokumen Welcome to Agro-Tour PG Pangka-Central Java.

${ }^{13}$ Dokumentasi Temanten Tebu, 2008.

${ }^{14}$ Wawancara dengan Bapak Sukoco tanggal 2 Oktober 2009 dan Bapak Supeno tanggal 14 Oktober 2009.

${ }^{15}$ Wawancara tanggal 14 Oktober 2009.

${ }^{16}$ Franz Magnis Suseno, Etika Jawa: Sebuah Analisa Falsafi Tentang Kebijaksanaan Hidup Jawa (Jakarta: PT. Gramedia, 1984).

${ }^{17} \mathrm{Ibid}$.

${ }^{18}$ Retno Sayekti, Upacara Tradisional .

${ }^{19}$ Wawancara, tanggal 16 Oktober 2009.

${ }^{20}$ Wawancara dengan KH. Mubasyir Dahlan, tanggal 14 Oktober 2009.

\section{H. DAFTAR PUSTAKA}

Abdullah, Amin. 1996. Studi Agama, Normatifitas dan Historisitas. Yogyakarta: Pustaka Pelajar.

Afandi, Arief. 1996. Islam, Demokrasi Atas Bawah. Yogyakarta: Pustaka Pelajar. Amin, H.M. Darori (Ed.). 2002. Islam dan Kebudayaan Jawa. Yogyakarta: Gama Media.

Beatty, Andrew. 2001. Variasi Agama di Jawa, Suatu Pendekatan Antropologi. Jakarta: PT. Raja Grafindo Persada.

Baso, Ahmad dkk. 2003. Islam Pribumi (Mendialogkan Agama Membaca Realitas). Jakarta: Penerbit Erlangga.

Brosur PG Pangkah. Argowisata "LOCO-ANTIK" PG. Pangkah.

Coward, Harold. 1997. Setting the Reseach For Canadian Religious Pluralism, ARC 25, 1997

Dokumen PG Pangka. Welcome to argo Tour PG Pangkah Central Java.

Endraswara, Suwardi. 2004. Mistik Kejawen: Sinkretisme, Simbolisme dan Sufisme dalam Budaya Spiritual Jawa. Yogyakarta: NARASI.

Ettinghausen, Richard. TT. "Interaksi dan Integrasi dalam Seni Islam", dalam

Gustave E. Von Grunebaum (Ed.), Islam Kesatuan dalam Keragaman. Terj.

Effendi N. Yahya. Jakarta: Yayasan Perkhidmatan.

Foster, George M. 1969. Applied Antrhropology. Boston: Little Brown Company. Geertz, Clifford. 1989. Abangan, Santri, Priyayi dalam Masyarakat Jawa. Terj. Aswab Mahasin. Jakarta: Pustaka Jaya, 1989.

Harjana, AM. 1993. Penghayatan Agama: Yang Otentik dan Tidak Otentik. Yogyakarta: Kanisius. 
Haviland, William. 1998. Antropologi. Terj. Soekarjo. Jakarta: Airlangga. htip:/student.ukdw.ac.id/ 220126211/adat.html.

http: www.Iitagama.org/jurnal/edisi2/upacara.htm Izebigovic, Alija. 1992. Membangun Jalan Tengah. Bandung: Mizan.

Kaplan, David dan Albert A Manners. 1999. Teori Budaya. Terj. Landung Simatupang. Yogyakarta: Pustaka Pelajar.

Koentjarajakti. 1992. Sejarah Teori Antropologi. Jakarta: UI Press.

Koentjaraningrat. 1984. Kebudayaan Jawa. Jakarta: Balai Pustaka. 1975. Manusia dan Kebudayaan di Indonesia. Jakarta: Jambatan.

Jakarta: Gramedia.

Madjid, Nurcholish. 2000. Islam, Doktrin dan Peradaban. Jakarta: Paramadina. Misbah, M. 2005. "Islam Kultural (Telaah at as Pemikiran Abdurrahman Wahid)" dalam Ibda', Vol 3 No. 1, Januari-Juni 2005 (Purwokerto: P3M STAIN Purwokerto).

Miles, Matthew, and Michel Huberman. 1992. Qualitative Data Analysis. Terj. Tjejep Rohendi Rohidi, Analisa Data KualitatifBuku Sumber Tentang Metode Metode Baru. Jakarta: UI-Press.

Muhadjir, Noeng. 1996. Metodologi Penelitian Kualitatif. Yogyakarta: Rake Sarasin.

Munawwir, Ahmad Warson. 1997. Kamus al Munawwir Yogyakarta: Pustaka Progressif.

Onghokham. TT. Rakyat dan Negara. Jakarta: Yayasan Obor.

Patiroy, Ahmad. 2001. "Ritus Ruwahan dalam Kehidupan Keagamaan, dalam Jurnal Penelitian Agama, Vol. X. No. 1 Januari-April 2001 (Yogyakarta: Pusat Penelitian IAIN Sunan Kalijaga, 2001.

Prisma, 05 Mei 1995.

Ridwan, "Dialektika Islam dan Budaya Jawa", dalam Jurnal Ibda', Vol. 3, Nomor 1, Januari-Juni 2005, Purwokerto: P3M STAIN Purwokerto

Saidi, Anas. TT. Makalah-Makalah Metodologi Penelitian. Jakarta: LIPI. (Hanya Untuk Kalangan Sendiri).

Salim, Irfan. Islam dan Akulturasi Budaya Lokal, dalam http://media.isnet.org/ islam/Etc/Akulturasi.html.

Shihab, Quraish. 2001. Tafsir al Mishbah, Vol 5. Jakarta: Lentera Hati.

Simuh. 1995. Jawa, Transformasi Tasawuf ke Mistik Jawa. Yogyakarta: Bentang Budaya.

Sofwan, Ridin, dkk. 2004. Islamisasi di Jawa. Yogyakarta: Pustaka Pelajar.

Wahid, Abdurrahman. 1999. Membangun Demokrasi. Bandung: Remaja Rosdakarya.

www.indosiar.com/news/fokus/50390_ritual-tebu-manten-jelang-panen-rayatebu-23k-yang diakses tanggal 1 Mei 2009. 